\title{
A cell line (EP-1 cell line) derived from "Beko disease" affected Japanese eel elver (Anguilla japonica) persistently infected with Pleistophora anguillarum
}

\author{
Guang-Hsiung Kou ${ }^{\text {a }}$, Chung-Hsiung Wang ${ }^{\text {b }}$, Hsu-Wei Hung ${ }^{\text {a }}$, \\ Yun-Shiang Jang ${ }^{\text {a }}$, Chih-Ming Chou ${ }^{a}$, Chu-Fang Lo ${ }^{\text {a,* }}$ \\ a Department of Zoology, National Taiwan University, Taipei, Taiwan 107, ROC \\ b Department of Plant Pathology, National Taiwan University, Taipei, Taiwan 107, ROC
}

\begin{abstract}
Tissues collected from Japanese eel elver (Anguilla japonica) experimentally infected with Pleistophora anguillarum were cultivated in Leiboritz's L-15 medium. A cell line designated as EP-1 (eel cells persistently infected with $P$. anguillarum) was established, and was found to be persistently infected with $P$. anguillarum. With this culture system, we first described the merogonial reproduction of $P$. anguillarum. Using histochemical and indirect immunofluorescent technique, it was revealed that there were 3-4 merozoites of different sizes residing in the cytoplasm of EP-1 cells. Electron micrographs of EP-1 cells showed that the merogonial stages had isolated nuclei (monokaryotic). The merozoite plasmalemma was separated from host cytoplasm by a membrane of host origin. The results of the infection experiment revealed that the present in vitro cultivation system could provide infective merozoites which were capable of proceeding to further sporogonial reproduction in the muscle of their natural host, eels.
\end{abstract}

Keywords: Pleistophora anguillarum; Microspora; Beko disease of eel; Anguilla japonica

\section{Introduction}

Members of the phylum Microspora are obligate intracellular parasites found in many invertebrates and vertebrates (Sprague, 1977). They have been especially important as pathogens of insects, fishes, and laboratory animals. Recently, at least four genera (Ence-

* Corresponding author. 
phalitozoon, Nosema, Pleistophora, and Enterocytozoon) have been recognized in human tissues and may become important pathogens for immunosuppressed individuals, including AIDS patients (Shadduck and Greeley, 1989; Didier et al., 1991).

During the last two decades, most of the available knowledge related to the cultivation of microsporidia has been obtained through the study of in vitro cultivation of insect microsporidia (Ishihara and Sohi, 1966; Ishihara, 1969; Kurtti and Brooks 1977; Kawarabata and Ishihara, 1984). The establishment of insect cell lines in this period made the in vitro cultivation of the parasites practical in many laboratories. In this field, Nosema is the best studied genus. The continuous propagation of parasites in insect cell lines was done by inoculating insect cell lines with spores or co-cultivating insect cell lines with tissues collected from diseased insects (Sohi and Wilson, 1976; Kurtti and Brooks, 1977; Streett et al.,1980; Kawarabata and Ishihara, 1984). To support the continuous propagation of parasites, it was usually necessary for healthy cells be added to the culture system. The insect microsporidia, for example Nosema, could complete their life cycle within one cell. Both merogony and sporogony were readily observed in insect cells (Kawarabata and Ishihara, 1984).

With regard to the fish microsporidia, 12 genera have been described (Sprague, 1977; Canning and Lom, 1986; Faye et al., 1990, 1991). Although they have been studied extensively in the field of pathology, histology, and ultrastructure in their natural hosts, none of them has been reported to be able to propagate in vitro in fish cell lines.

As a result of a 5-year trial and investigation, our laboratory has eventually succeeded in establishing in vitro cultivation systems for one kind of fish microsporidian, Pleistophora anguillarum. Pleistophora anguillarum is an important protozoan parasite which affects Japanese eel, Anguilla japonica (Hoshina, 1951). Sporogonial development of the parasite mainly occurs in skeletal muscle, resulting in body curvature and concave depressions on the body surface of the eels (T'sui and Wang, 1988; T'sui et al., 1988; Wang et al., 1990). Experimental induction of microsporidiosis in elvers was achieved by orally inoculating Pleistophora spores into elvers or immersing them in an aqueous suspension of fresh spores (Kano and Fukui, 1982; T'sui et al., 1988). The microsporidian could complete its life cycle in experimentally infected elvers within 13 days at $25^{\circ} \mathrm{C}$ ( $T$ 'sui et al., 1988). Although studies on this parasite had been well documented, the site for merogonial development remained unclear. No effective treatments in the field are known (Kano and Fukui, 1982). Although mortality is low, economic losses are important as the appearance of the fish makes them unsuitable for sale.

In this paper, we report the results of our study with an in vitro cultivation system of $P$. anguillarum. In addition, a discussion on the life cycle of $P$. anguillarum is also included, with emphasis on the site of merogonial reproduction in the natural host.

\section{Materials and methods}

Purification of spores for experimental infection of elvers

The spores were isolated from naturally infected eels and purified by Percoll (Pharmacia, Fine Chemicals) gradient centrifugation (T'sui et al., 1988). 


\section{Experimental infection of elvers}

The elvers, about $0.15 \mathrm{~g}$ in body weight, were immersed in a spore suspension, at a concentration of $10^{7}$ spores per $\mathrm{ml}$, at $25^{\circ} \mathrm{C}$ for $12 \mathrm{~h}$. The infected elvers were then cultured in laboratory aquaria and fed with oligochaetes. The infected elvers were sacrificed for establishment of cell cultures 12 days postinfection.

\section{Primary cell culture and subculture}

The body surfaces of experimentally infected elvers were sterilized with iodine alcohol and rinsed with sterilized distilled water. The elvers were dissected, and the infected tissues were minced with sterilized scissors and torn with forceps, then transferred to Corning 25 $\mathrm{cm}^{2}$, canted neck, tissue culture flasks (Corning Laboratory Sciences Company) with Leibovitz's L-15 medium (Life Techonologies, Inc.), supplemented with $20 \%$ heat-inactivated fetal calf serum (HIFCS), antibiotics (penicillin, $100 \mathrm{IU} / \mathrm{ml}$; streptomycin, 100 $\mu \mathrm{g} / \mathrm{ml}$ ), and fungizone (amphotericin $\mathrm{B}, 2.5 \mu \mathrm{g} / \mathrm{ml}$ ). The cells were incubated at $28^{\circ} \mathrm{C}$ and, upon reaching confluency, monolayers were subcultured using $0.1 \%$ trypsin in phosphate-buffered saline (PBS) with a split ratio of 1:3. After the 50th passage, the cells were grown in L-15 medium supplemented with $10 \%$ HIFCS. Three established cell lines persistently infected with $P$, anguillarum were obtained and one of them was designated as EP-1 cells for use in the present study.

\section{Karyology and cell growth curve}

Karyotype was determined by the procedure described by Humason (1979). Briefly, the EP-1 cells, from an exponentially growing culture, were arrested at metaphase by incubating them with demecolcin (Sigma) at a concentration of $0.06 \mu \mathrm{g} / \mathrm{ml}$ for $5 \mathrm{~h}$. Thereafter, the cells were hypotonically treated and then fixed in 3:1 methanol-acetic acid. The fixed cells were then dropped vertically onto one end of the slides, whereafter the slides were slanted to allow the cells to drain downward. Subsequently, the preparations were air-dried and stained with Giemsa stain.

For the study of cell growth, $5.0 \times 10^{5}$ cells were seeded in a Corning $25 \mathrm{~cm}^{2}$ tissue culture flask with $3 \mathrm{ml}$ of culture medium. The cells were trypsinized and counted with a Neubauer hemocytometer at 6- or 12-h intervals. The number of cells per flask was plotted against time, and the logistic growth equations were determined. The population doubling time was estimated from the exponential equation (Kuchler, 1977).

\section{Feulgen reaction for detection of $P$. anguillarum in EP-1 cells}

A cover glass was placed in each well of a 24-well microplate (Nunc) and seed EP-1 cells were added at a density of $1 \times 10^{5}$ cells per well. At 1 - day intervals, one cover glass was removed out of the microplate and placed in Carnoy fixative. The fixed cell monolayers were then processed with Feulgen reaction (Humason, 1979). Mayer's hematoxylin-eosin (H-E) stained cell preparations were also made for comparison purposes. The observations were made with an Olympus BH-2 microscope.

\section{Indirect immunofluorescent assay for detection of $P$. anguillarum in EP-1 cells}

Rabbit antisera against spore soluble proteins of $P$. anguillarum were prepared as follows: The spores purified by Percoll gradient centrifugation were diluted 10 times with PBS and centrifuged at $550 \times g$ for $140 \mathrm{~min}$. The pellet was resuspended with PBS to make a 
suspension with a concentration of $10^{9}$ spores $/ \mathrm{ml}$. A 2-ml spore suspension was homogenized at a low temperature with the Polytron PT 10-35 homogenizer (Kinematica) using PTA TK aggregate. The homogenate was harvested at 15 -min intervals, and extracted with equal volume of Freon 113 . The aqueous layer was collected after centrifugation at $1000 \times \mathrm{g}$ for $10 \mathrm{~min}$. The soluble proteins $(500 \mu \mathrm{l})$, mixed with equal volume of Freund's complete adjuvant, were used for antisera production by hyperimmunization of a rabbit. The antisera were preabsorbed with freeze-dried muscle from healthy eel in order to eliminate the nonspecific reaction. The absorbed antisera were used for the present studies.

The EP-1 cell monolayers grown on the rounded cover glasses were fixed in cold absolute acetone. The fixed cell monolayers were then washed in PBS and reacted with antisera against $P$. anguillarum at $37^{\circ} \mathrm{C}$ for $1 \mathrm{~h}$. After washing, the fixed cell monolayers were then reacted with FITC-conjugated goat anti-rabbit IgG (Jackson Immuno Research Laboratories Inc.), and counterstained with $0.025 \%$ Evans blue. The observations were made with an Olympus BH-2 fluorescence microscope.

\section{Electron microscopy for detection of $P$. anguillarum in EP-I cells}

The EP-1 cells were trypsinized and suspended in culture medium. The cells were pelleted by centrifugation at $800 \mathrm{rpm}$ for $5 \mathrm{~min}$ at $4^{\circ} \mathrm{C}$, then fixed in $2.5 \%$ glutaraldehyde in $\mathrm{pH} 7.2$, $0.1 \mathrm{M}$ phosphate buffer at $4^{\circ} \mathrm{C}$ for $3 \mathrm{~h}$. The following postfixation was carried in $1 \%$ osmic tetraoxide in $\mathrm{pH} 7.2,0.05 \mathrm{M}$ phosphate buffer at $4^{\circ} \mathrm{C}$ for $2 \mathrm{~h}$. After several steps of dehydration, the cell blocks were then embedded in Spurr epon. The ultrathin sections were stained with uranyl acetate and lead hydroxide. Electron micrographs were taken with an Hitachi TEM 600.

Infection experiment for detection of infective forms of $P$. anguillarum in EP-1 cell culture system

The EP- 1 cell cultures were collected at passage 140 , and centrifuged at $1000 \mathrm{rpm}$ for 10 min. The cell pellets, resuspended with PBS, were used for detection of infective forms of $P$. anguillarum. Four young eels, about 15 to $20 \mathrm{~cm}$ in length, were injected with $0.1 \mathrm{ml}$ infected cell suspension (dose, ca. $10^{5}$ cells/fish) by subdermal injection using a No. 25 needle. Twenty days after inoculation, experimental eels were sacrificed and tissue smears were made for examination of $P$. anguillarum spores. Another four young ccls wcre treated as controls by injecting $0.1 \mathrm{ml}$ PBS instead of EP-1 cell suspension.

\section{Results}

\section{Primary cell culture and subculture}

Immediately after starting the culture, most explants were observed to attach themselves to the tissue culture flasks. A significant cell outgrowth and obvious cell multiplication occurred in some flasks after 5 days while other flasks required up to 2 months. After 10 weeks, the primary culture in several flasks reached confluency and the initial subculture was made at this time. The subsequent subcultures were performed at 10-15-day intervals during the first 20 passages, and then more frequently, 4-6-day intervals, depending on time to confluency. Eventually, at least three cell lines with obviously different morphology were 

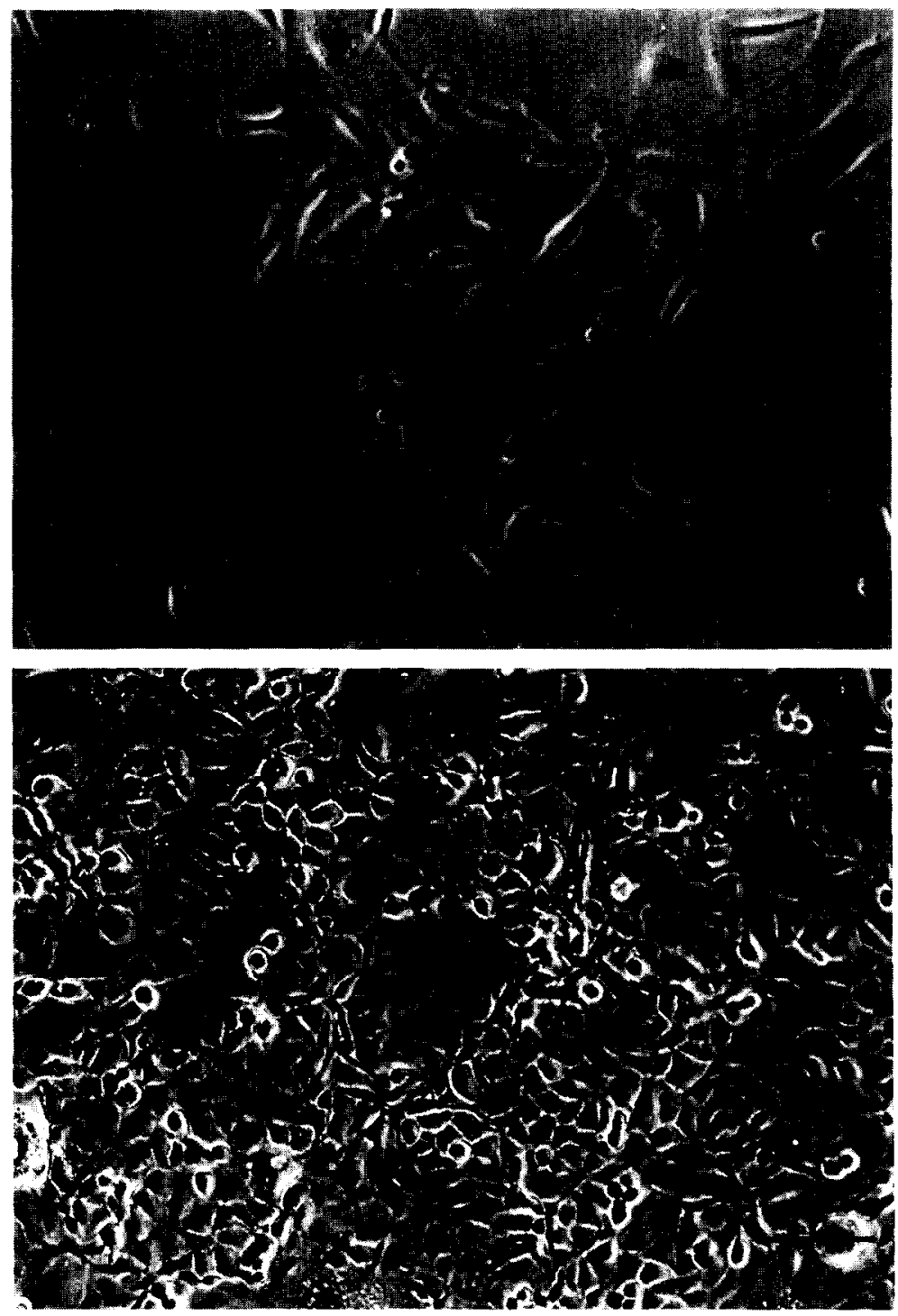

Fig. 1. Morphology of EP-1 cell line. A, EP-1 in low density cultivation. B, EP-1 cells in confluent cultivation. Bar: $50 \mu \mathrm{m}$.

established. In this paper, we present the investigation results of EP-1 cells. The EP-1 cells had been passaged over 223 generations (from June 1988 to October 1992) and are still maintained in L-15 medium supplemented with 10\% HIFCS in our laboratory.

EP-1 cells consisted of closely packed squamous cells that grew as monolayers (Fig. 1). The majority of the cells were polygonal. A few giant squamous cells and fibroblast-like cells were interspersed among the dominant cells. Usually, the cells had one centrally located nucleus. However, cells with 2-4 nuclei were occasionally seen (Fig. 2A). EP-1 cells 

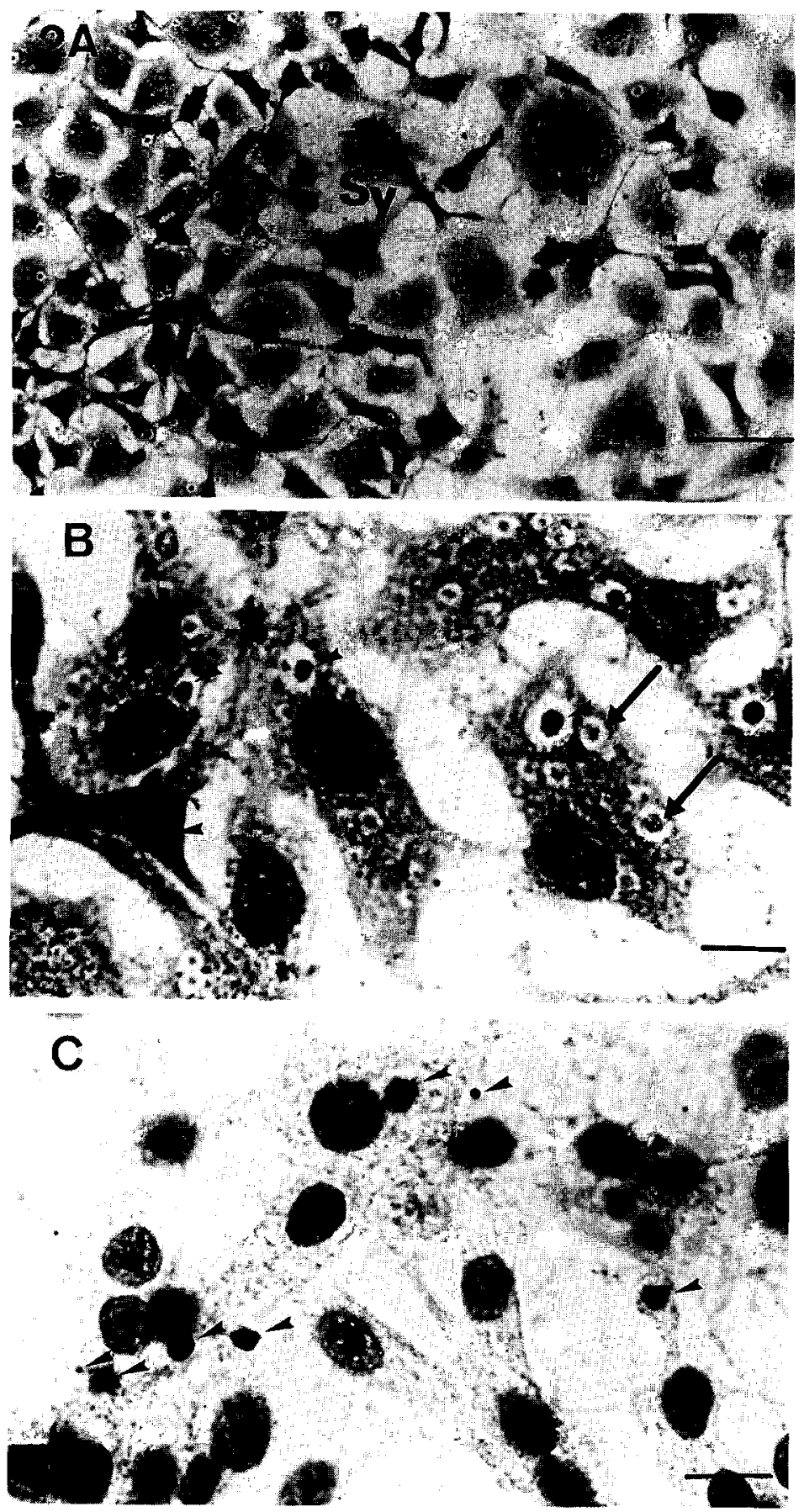

Fig. 2. Fixed and stained EP-1 cells in monolayers. A, hematoxylin-eosin-stained EP-1 cells at low magnification showing giant squamous cells (Sq) and syncytial cells (Sy) interspersed among dominant cells. Bar: $50 \mu \mathrm{m}$. B, hematoxylin-eosin-stained EP-1 cells at high magnification showing the merozoites (arrowheads) of Pleistophora anguillarum and acidophilic vacuoles (arrows) in the cytoplasm. Bar: $20 \mu \mathrm{m}$. C, Feulgen stained EP- 1 cells showing merozoites of Pleistophora anguillarum in the cytoplasm (arrowheads). Bar: $20 \mu \mathrm{m}$. 


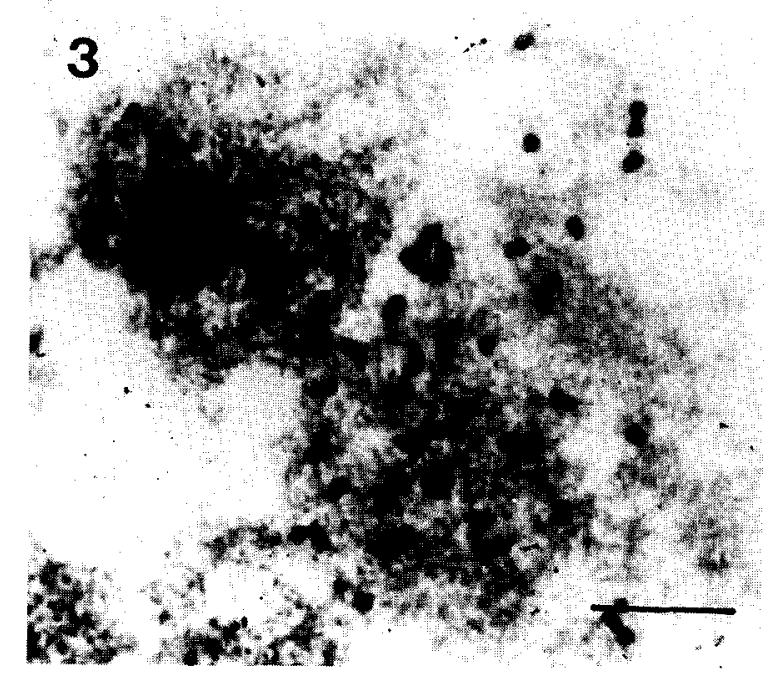

Fig. 3. Karyotype of EP-1 cells. The sample preparation was stained with Giemsa. Bar: $10 \mu \mathrm{m}$.

produced mucin, as a result of which the culture medium appeared to be viscous. The viscosity of the culture medium increased over time within each generation. There were many acidophilic vacuoles in EP-1 cytoplasm which weakly stained with $\mathrm{H}-\mathrm{E}$ stain but showed Feulgen negative reaction (Figs. 2D and 2C). These acidophilic vacuoles were thought to be responsible for the mucin production.

Chromosome analyses showed that EP-1 cells were all heteroploid and that the chromosome numbers of cultured cells varied greatly in the cell population. EP- 1 cells at passage 80 had chromosome numbers which varied widely from 11 to 43 , with a modal number of 32 (Figs. 3 and 4). The study of cell growth showed that the doubling time of EP-1 cells during the logarithmic phase of growth was approximately $47 \mathrm{~h}$ (Fig. 5 ).

\section{Feulgen reaction for detection of $P$. anguillarum in EP-I cells}

The merozoites of $P$. anguillarum resided in the cytoplasm of EP-1 cells (Fig. 2) The merozoites were spherical, 2 to $18 \mu \mathrm{m}$ in diameter, and contained a nucleus which stained deeply with hematoxylin. Secing that the existence of mucin vacuoles may lead to confusion with $P$. anguillarum, the Feulgen stain was further used to more definitely detect the parasite (Fig. 2C).

The histochemical properties of merozoites of $P$. anguillarum and their host cells were distinct in Feulgen reagent staining. The nucleus of the merozoites stained deep purple while that of host cells stained pink. Furthermore, when using fast green stain, the cytoplasm of the parasite stained deeper than that of the host cells. The merozoites were rounded or slightly irregular cells, $2-25 \mu \mathrm{m}$ in diameter, with a central nucleus, $1-11 \mu \mathrm{m}$ in diameter. The results indicated that merozoites in EP-1 cells could grow and then increase their size more than 10 times.

The cytoplasm of an EP- 1 cell usually contained 1 to 10 merozoites, depending on the number of days after subculture. In general, the lowest number of merozoites occurred on 


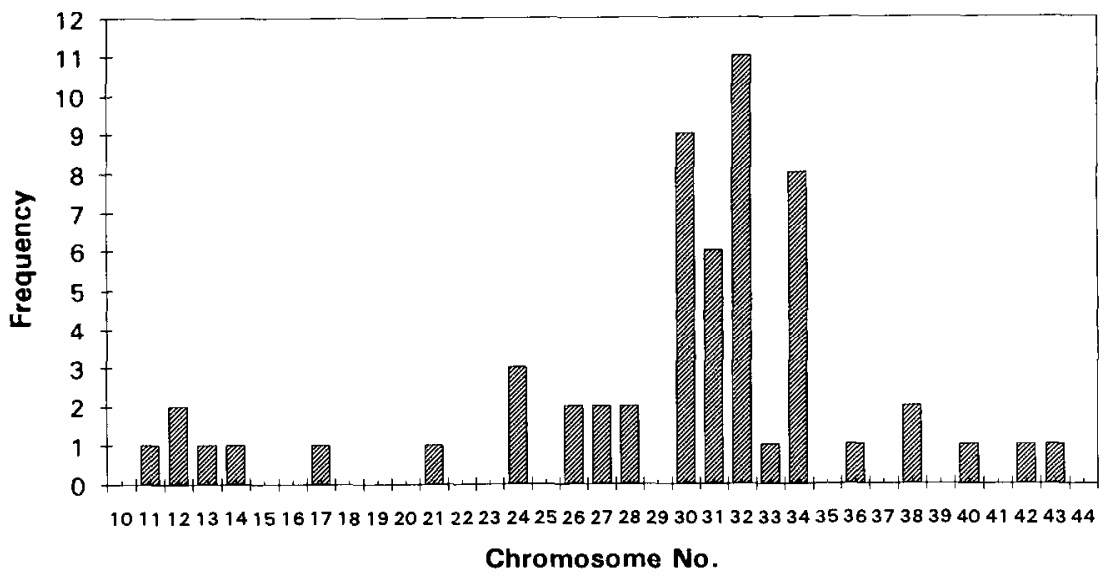

Fig. 4. Histogram of chromosome number of EP-1 cells at the metaphase.

day 3, with the highest number on the first and last day of any given subculture. Differentiation of merozoites into sporonts has not yet been observed in this culture system. It was unnecessary to add healthy cells into this culture system in order to support the continuous propagation of the parasite. The mechanisms involved in maintaining the balance between the parasites and the host cells remain unclear.

Indirect immunofluorescent assay for detection of $P$. anguillarum in EP-1 cells

The merozoites of $P$. anguillarum could also be detected by the indirect immunofluorescent technique (IFAT). The merozoites in the cytoplasm of EP-1 cells reacted strongly with antisera against soluble proteins extracted from $P$. anguillarum spores (Fig. 6). This result confirmed that the parasite in EP-1 was $P$. anguillarum.

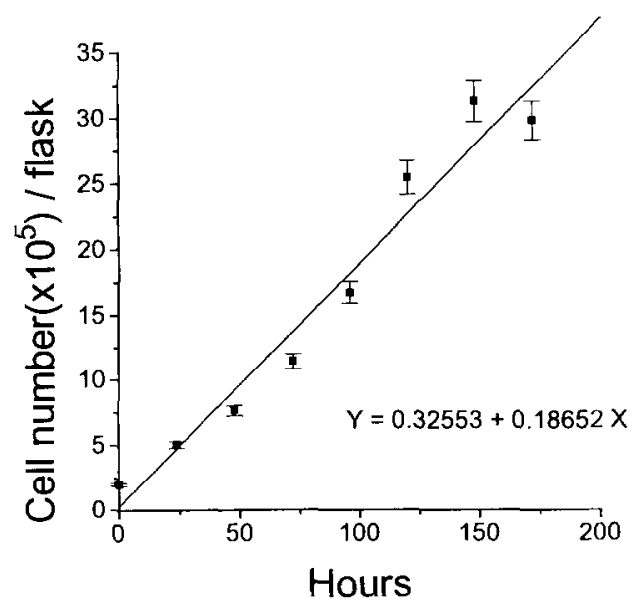

Fig. 5. Growth curve for EP-1 cell line in L-15 medium supplemented with 10\% HIFCS. The population doubling time during the logarithmic phase of growth was approximately $47 \mathrm{~h}$. 


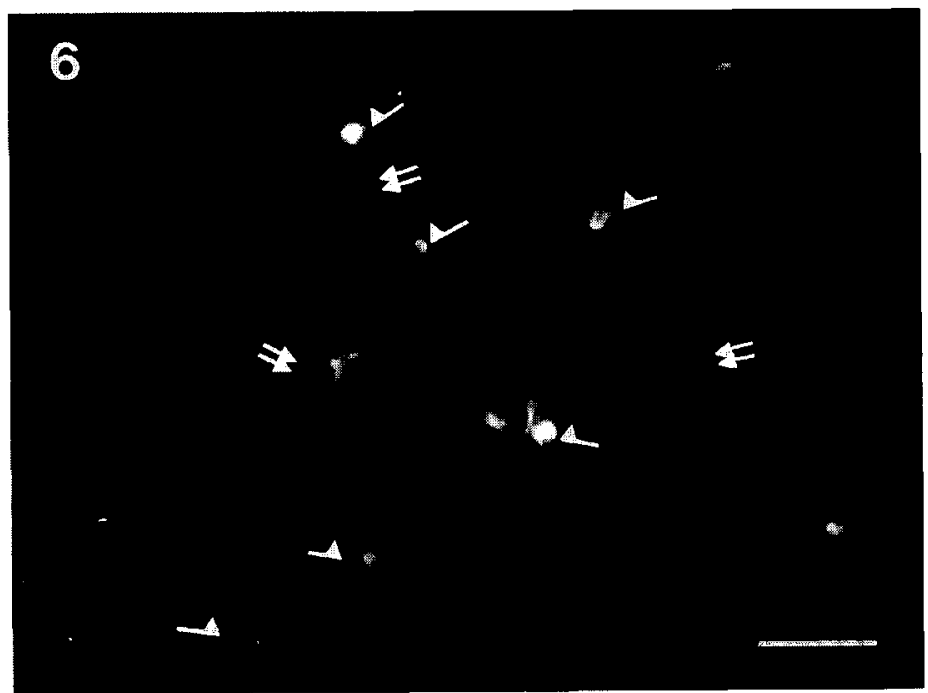

Fig. 6. Positive reaction of Pleistophora anguillarum antisera with merozoites (single arrows) in EP-1 cells (double arrows) by indirect fluorescent antibody techniques. Bar: $20 \mu \mathrm{m}$.
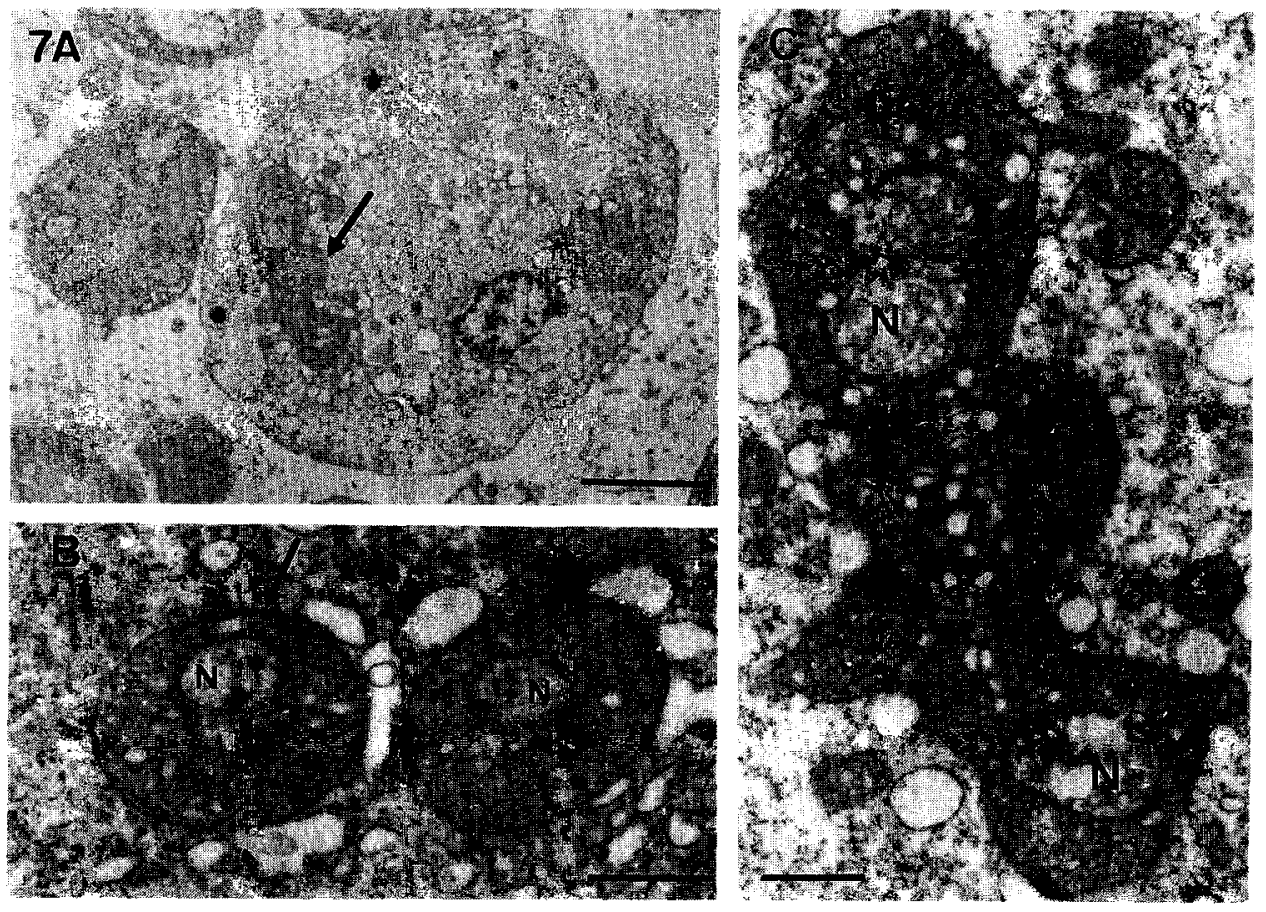

Fig. 7. Electron micrographs of EP-1 cells. A, merozoite of $P$. anguillarum (arrow) in cytoplasm of an EP-1 cell. Bar: $5 \mu \mathrm{m}$. B, a membrane (arrow) of host origin separating the merozoite from the host cytoplasm. N: nucleus of merozoite. Bar: $1 \mu \mathrm{m} . \mathrm{C}$, closed intracellular pleuromitosis (arrow) in a merozoite. $\mathrm{N}$ : nucleus of merozoite. Bar: $1 \mu \mathrm{m}$. 
Electron microscopy for detection of $P$. anguillarum in EP-1 cells

Electron micrographs of cultured EP-1 cells showed that the merogonial stages had isolated nuclei (monokaryotic). Merozoites were rounded or occasionally irregular cells with one or more nuclei (Fig. 7A). The merozoite plasmalemma was separated from the host cytoplasm by a membrane which appeared to be of host origin and was similar to that of membrane-bound vesicles (Fig. 7B). All merogonial stages in the cytoplasm of EP-1 cells lack mitochondria and golgi apparatus. The nucleus was vesicular and mostly with diffuse chromatin. Nucleoli were not observed.

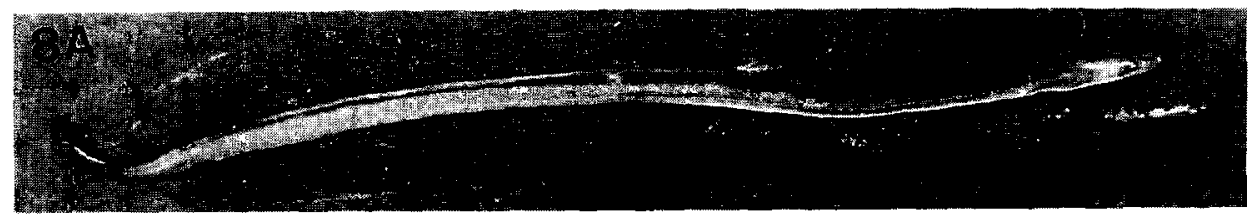

B
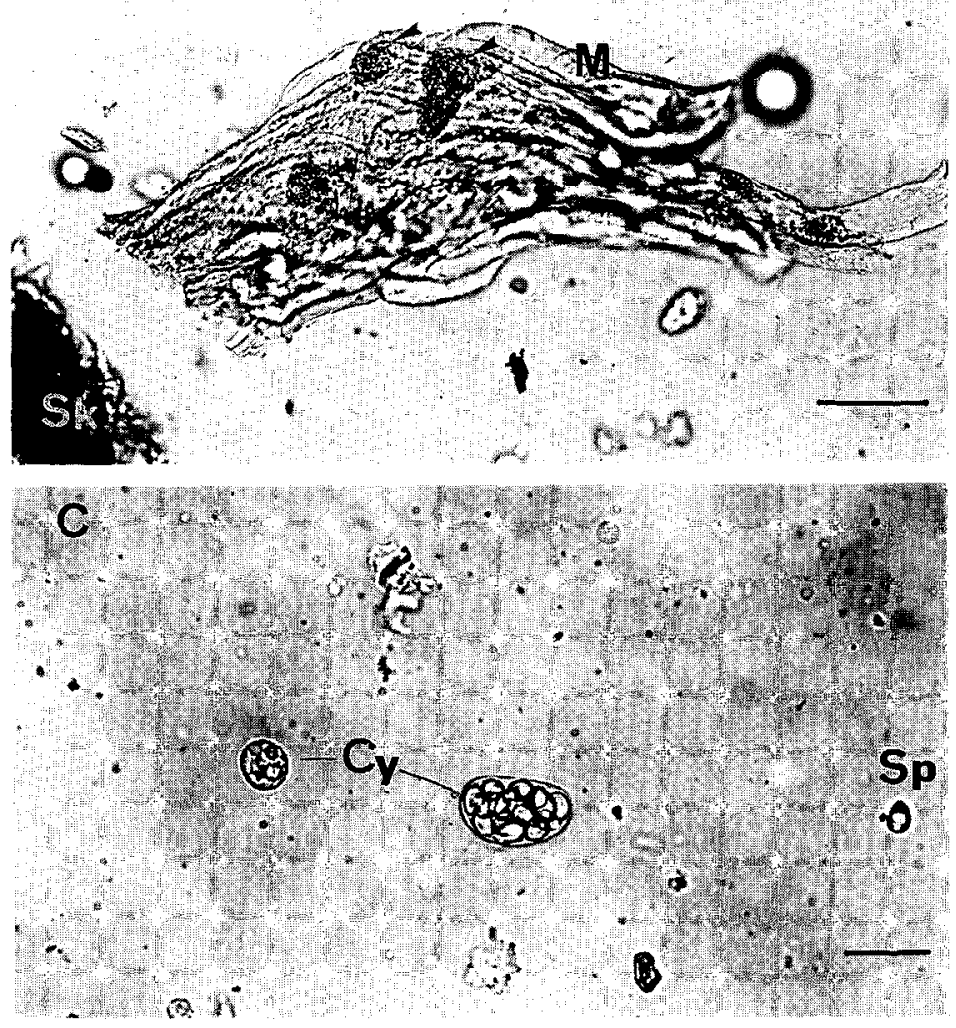

Fig. 8. A young eel, 20 days postinoculation with a suspension of EP-1 cell culture medium. A, dorsal view of the inoculated eel showing the obvious foci on the body surface (arrowhead). Bar: $2 \mathrm{~cm}$. B, tissues from inoculated site of the artificially injected eel indicating the cysts (arrowheads) in muscle bundles (M). Sk: skeletal muscle. Bar: $100 \mu \mathrm{m}$. C, two cysts (Cy) with mature spores (Sp). Bar: $20 \mu \mathrm{m}$. 
Closed intracellular pleuromitosis occurring in a merozite of $P$. anguillarum is shown in Fig. 7C.

Infection experiment for detection of infective forms of $P$. anguillarum in $E P-I$ cell culture system

Twenty days postinoculation, obvious foci appeared on the body surface at the sites of injection in all the experimental eels (Fig. 8A). Micrographs of tissue smears made from experimental eels showed the developing cysts in the muscle bundle of an eel (Figs. 8B and $8 \mathrm{C}$ ). Four young eels treated as controls remained uninfected with $P$. anguillarum. These results reconfirmed that the EP-1 cell line was persistently infected with $P$. anguillarum. The present in vitro cultivation system could provide infective merozoites capable of continuing sporogonial reproduction in the muscle of their natural host, eels.

\section{Discussion}

Our previous studies on the development of $P$. anguillarum in experimentally infected elvers, Anguilla japonica, showed that there were many plasmodia in the muscle of the experimental elvers at 12 days postinfection and no secondary infection was observed in the infected sites ( T'sui et al., 1988). Thus, we used the tissues from experimentally infected elvers at 12 days postinfection for in vitro cultivation of plasmodia. Unexpectedly, instead of a free form of plasmodia, several cell lines, including EP-1 cells for use in the present study, were established and all of them were persistently infected with merozoites of $P$. anguillarum. Several topics including the development of $P$. anguillarum and the hostparasite relationship in EP cells are being investigated. The stages of $P$. anguillarum in EP1 cells remain to be specified, but we assume that the present in vitro cultivation system of $P$. anguillarum has a potential value for further studies of "Beko disease" in the eel.

It is well known that two proliferative sequences, merogony and sporogony, occur in microsporidian development. Merogony, the vegetative reproduction, is of short duration and easily overlooked. Most species of microsporidia were described from the developmental stages observed in naturally infected hosts in which they were sporulating, and a preceding merogony could not always be seen (Larsson, 1986). Merogony and sporogony may occur in the same host tissue, in different tissues of the same host, or in different generations of the host species (Gray et al., 1969; Andreadis, 1983; Hazard et al., 1984; Larsson, 1986). In P. anguillarum, sporogony, the production of spores, the ultimate stage in development, occurs mainly in the skeletal muscle of eels. Merogonial production has not previously been observed. The small dimension of the merozoites, as well as the different tissues involved in merogonial and sporogonial development of $P$. anguillarum, made proper interpretation difficult before the use of a fish cell line for culturing the merogonial stages. Based on the present results, $P$. anguillarum merogonial reproduction may occur in tissues different from skeletal muscle, such as eel epithelium. The present data showed that epithelial cells could support the proliferation of merozoites because EP- 1 cells were derived from eel epithelial cells. Nevertheless, further studies are necessary to delineate the contributory role of merozoites, proliferating in eel epithelial cells, to the skeletal muscle infection. 
Documented cases of clinically significant microsporidiosis in humans are increasing in association with the increase in patients with AIDS (Didier et al., 1991). One case of human infection thought to be due to a parasite belonging to the genus Pleistophora has been reported. In this patient, atrophic and degenerating muscle fibers were infiltrated by spores. Pleistophora anguillarum also made the skeletal muscle of the affected eel degenerate and atrophy. The relationship between human Pleistophora and $P$. anguillarum is not yet clear. However, attempts to grow parasites from human specimens are strongly encouraged since this approach might result in recovery of human isolates (Shadduck and Greeley, 1989). Our studies on the in vitro cultivation of $P$. anguillarum may provide valuable information not only for the study of fish but also human Pleistophora infections.

\section{Acknowledgements}

This research was supported by the National Science Council (NSC 82-0211-B-002046), ROC.

\section{References}

Andreadis, T.G., 1983. Life cycle and epizotiology of Amblyospora sp. (Microspora: Ambylosporidae) in the mosquito, Aedes cantator. J. Protozool., 30: 509-518.

Canning, E.U. and Lom, J., 1986. The Microsporidia of Vertebrates. Academic Press, Orlando, Florida, 289 pp.

Didier, E.S., Didier, P.J., Friedberg, D.N., Stenson, S.M., Orenstein, J.M., Yee, R.W., Tio, F.O., Davis, R.M., Vossbrinck, C., Millichamp, N. and Shadduck, J.A., 1991. Isolation and characterization of a new human microsporidian, Encephalitozoon hellem (n. sp.), from three AIDS patients with keratoconjunctivitis. J. Infect. Dis., 163: 617-621.

Faye, N., Toguebaye, B.S. and Bouix, G., 1990. Ultrastructure and development of Pleistophora senegalensis sp. nov. (Protozoa, Microspora) from the gilt-head sea bream, Sparus aurata L. (Teleost, Sparidae) from the coast of Senegal. J. Fish Dis., 13: 179-192.

Faye, N., Toguebaye, B.S. and Bouix, G., 1991. Microfilum lutjani n. g. n. sp. (Protozoa Microsporida), a gill parasite of the golden African snapper Lutjanus fulgens (Valenciennes, 1830) (Teleost Lutjanidae): developmental cycle and ultrastructure. J. Protozool, 38(1): 30-40.

Gray, F.H., Cali, A. and Briggs, J.D., 1969. Intracellular stages in the life cycle of the microsporidian Nosema apis. J. Invertebr. Pathol., 14: 391-394.

Hazard, E.I., Fukuda, T. and Becnel, J.J., 1984. Life cycle of Culicosporella lunata (Hazard and Savage, 1970) Weiser, 1977 (Microspora) as revealed in the light microscope with a redescription of the genus and species. J. Protozool., 31: 385-391.

Hoshina, T., 1951. On a new microsporidian, Pleistophora anguillarum n. sp., from the muscle of the eel, Anguilla japonica. J. Tokyo Univ. Fish., 38: 35-49.

Humason, G.L., 1979. Animal Tissue Techniques. W.H. Freeman and Company, San Francisco, 661 pp.

Ishihara, R., 1969. The life cycle of Nosema bombycis as revealed in tissue culture cells of Bombyx mori. J. Invertebr. Pathol., 14: $316-320$.

Ishihara, R. and Sohi, S.S., 1966. Infection of ovarian tissue culture of Bombyx mori by Nosema bombycis spores. J. Invertebr. Pathol., 8: 538-540.

Kano, T. and Fukui, H., 1982. Studies on Pleistophora infection in eel, Anguilla japonica. I. Experimental induction of microsporidiosis and fumagilline efficacy. Fish Pathol., 16: 193-300.

Kawarabata, T. and Ishihara, R., 1984. Infection and development of Nosema bombycis (Microsporida: Protozoa) in a cell line of Antheraea eucalypti. J. Invertebr. Pathol., 44: 52-62. 
Kuchler, R.J., 1977. Biochemical Methods in Cell Culture and Virology. Dowden, Hutchinson and Ross, Inc., $331 \mathrm{pp}$.

Kurtti, T.J. and Brooks, M.A., 1977. The rate of development of a microsporidian in moth cell culture. J. Invertebr. Pathol., 29: 126-132.

Larsson, R., 1986. Ultrastructure, function and classification of Microsporida. In: J.O. Corliss and D.J. Patterson (Editors), Progress in Protistology, I. Biopress Ltd., UK, pp. 325-390.

Shadduck, J.A. and Greeley, E., 1989. Microsporidia and human infections. Clin. Microbiol. Rev., 2: 158-165.

Sohi, S.S. and Wilson, G., 1976. Persistent infection of Malacosoma disstria (Lepidoptera: Lasiocampidae) cell cultures with Nosema (Glugea) disstria (Microsporida: Nosematidae). Can. J. Zool., 54: 336-342.

Sprague, V., 1977. Systematics of the Microsporidia. In: L.A. Bulla Jr. and T.C. Cheng (Editors), Comparative Pathobiology, 2. Plenum Press, New York, 510 pp.

Streett, D.A., Ralph, D. and Hink, F., 1980. Replication of Nosema algerae in three insect cell lines. J. Protozool., 27: 113-117.

T'sui, W.H. and Wang, C.H., 1988. On the Pleistophora infection in eel. I. Histopathology, ultrastructure and development of Pleistophora anguillarum in eel, Anguilla japonica. Bull. Inst. Zool., Acad. Sin., 27: 159166.

T'sui, W.H., Wang, C.H. and Lo, C.F., 1988. On the Pleistophora infection in eel. II. The development of Pleistophora anguillarum in experimentally infected elvers, Anguilla japonica. Bull. Inst. Zool., Acad. Sin., 27: $249-258$.

Wang, C.H., Shia, W.L., Chang, Y.S., Lo, C.F. and Kou, G.H., 1990. The studies of "Beko disease" in eel. In: G.H. Kou, H. Wakabayashi, I.C. Liao, S.N. Chen and C.F. Lo (Editors), Proceedings of ROC-Japan Symposium on Fish Diseases, 6-7 November 1989, at Taipci, Taiwan, ROC. 